九州大学学術情報リポジトリ

Kyushu University Institutional Repository

\title{
A NEW SPECIES OF THE GENUS SYNECHES FROM BORNEO (DIPTERA, EMPIDIDAE)
}

Saigusa, Toyohei

https://doi.org/10.5109/2533

出版情報: ESAKIA. Special Issue 1, pp.111-114, 1990-04-20. Entomological Laboratory, Faculty of Agriculture, Kyushu University バージョン :

権利関係 : 


\title{
A NEW SPECIES OF THE GENUS SYNECHES FROM BORNEO (DIPTERA, EMPIDIDAE)
}

\author{
Toyohei Saigusa \\ Biological Laboratory, College of General Education, Kyushu University, \\ Ropponmatsu, Fukuoka, 810 Japan
}

\begin{abstract}
Synecheshirashimai sp. nov. from Borneo is described. It is similar to S. subdeficiens from the Philippines, but is distinguished from the latter by more weakly ornamented hind legs.
\end{abstract}

In this paper I describe a new species of the genus Syneches from Borneo based on a male specimen collected by Prof. Emer. Y. Hirashima. The genus Syneches is almost world-wide in geographical distribution, but it most prospers in the tropical and subtropical regions of eastern part of the Oriental Region and the Papuan Subregion. The present new species is unique in having the entirely yellowish thorax, yellowish front and middle legs, and dark hind legs paled around the femoro-tibia1 joints. The new species is the second known species of the genus from Borneo, but there are many undescribed species in this large island. I am sincerely grateful to Prof. Emer. Y. Hirashima for offering me the type material of the new species.

\section{Syneches hirashimai Saigusa, sp. nov}

ণ7. Coloration. Head blackish brown, face densely greyish pollinose, clypeus and ocellar tubercle polished, occiput rather thinly greyish brown pollinose ; eye reddish brown, antenna yellowish, apical $3 / 4$ of 3rd segment brownish ; arista black ; proboscis and palpus yellowish brown. Thorax reddish brown to dark yellowish brown, scutellum and postalar callus more yellowish ; mesonotum thinly brown pollinose, pleura much thinly yellowish pollinose. Front and middle legs including coxae yellow to pale yellowish brown; hind leg dark brown, with coxa and trochanter dark yellowish brown, distal $1 / 4$ of $f_{3}$ except extreme tip and basal $3 / 5$ of $t_{3}$ yellow. Wing uniformly greyish brown, slightly darker anteriorly, stigma slightly darker than ground colour, elongate, $0.6 \mathrm{X}$ as wide as cell $R_{2+3}$, extending to apical $4 / 5$ of costa of cell $R_{2+3}$; veins brown, slightly darker than ground colour ; halter brown, yellowish on shaft towards its base. Abdomen blackish brown, 1st tergum and anterior $1 / 3$ of 2 nd tergum yellowish brown, sterna yellow, becoming brownish on posterior segments, abdominal terga thinly brownish pollinose ; genitalia blackish brown.

Head more or less flattened, $0.95 \mathbf{x}$ as long as high, $1.4 \mathrm{X}$ as wide as high ; eyes touching on entire length of frons, distinctly flattened dorsally, upper facets much enlarged, slightly larger than $2 \mathrm{X}$ middle facet, lower facets somewhat enlarged again near posteroventral corner of eye. Ocellar tubercle $2.6 \mathbf{x}$ as long as high, median ocellus $1.5 \mathbf{x}$ as large as upper facets in diameter, 2 fine ocellar 
setae 3.6X as long as turbercle height and a weaker seta behind them. Postocular ciliation almost uniserial, tawny, occiput clothed laterally with longish yellow hairs. Antenna normal, relative lengths of 1 st to 3 rd segments $1: 2: 3 ; 2$ nd black setose, 3rd $1.7 \mathbf{x}$ as long as thick, oval, with a black dorsal seta at the middle, arista dorsodistal, tawny and bare. Proboscis nearly as long as head, with its apex extending to the level of 3rd antennal segment ; palpus $1 / 4$ as long as proboscis, slender, style-like, thickest at $2 / 3$, bearing several longish setae on middle $1 / 3$ and a longer apical seta nearly as long as palpus, palpus also clothed with many fine setulae.

Thorax moderately hump-backed, mesonotum (scutum+scutellum) $0.6 \mathbf{x}$ as high as long. Chaetotaxy : Mesothoracic setae black to blackish brown, acrosticals multiserial, rather short on anterior $1 / 2$ of mesoscutum, becoming longer, erect and decreasing in number on posterior $1 / 2$; dorsocentrals uniserial, ca 10 in number, but the row becoming obscure by scattering fine hairs behind humeral callus, the posteriormost dorsocentral $1.5 \mathrm{x}$ as long as scutellum; humeral callus with short fine hairs, 1 strong notopleural with a much weaker hair in front, a row of 3-4 fine hairs above the notopleural, a row of several supra-alars which are longer behind, 1 strong postalar with a minute hair in front ; scutellum with 12 marginal setae, of which a subapical pair is strongest.

Wing moderately broad, $3.1 \mathbf{x}$ as long as broad, apex rather bluntly pointed, $R_{2+3}$ very weakly sinuate towards costa near tip of stigma, $\mathrm{R}_{4+5}$ weakly arched anteriorly, then almost straight on its apical $1 / 4$, anterior marginal vein of discal cell distad to $\mathrm{r}-\mathrm{m}$ crossvein weakly arched anteriorly, Ml weakly convergent to $\mathrm{R}_{4+5}$ beyond the middle, $4.3 \sim$ as long as discal crossvein, discal crossvein straight, $\mathrm{M}_{3} 1.5 \mathbf{x}$ as long as discal crossvein, discal cell $0.28 \mathbf{x}$ as long as wing, anterodistal and posterodistal corners of the cell about $90^{\circ}$, squama black. Halter normal.

Legs moderately thick, clothed with dark brown to black setae and bristles. Front leg : F, 5.9 x as long as thick, short-setose above, beneath with longish setae of which several av and pv ones are longer than $\mathrm{f}_{1}$ thickness ; $\mathrm{t}_{1} 8 \times$ as long as thick, thickest at 0.24 , gradually tapering apically, with 4 suberect dorsal setae ( $1.6 \mathrm{x} \mathrm{t}_{1}$ thickness), beneath with longish yellow setae, mixing 3-4 longer av setae (2.9 $\times \mathrm{t}_{1}$ thickness) ; front tarsus simple, each tarsomere with 1-2 longish dorsal setae subapical$\mathrm{ly}$, long hairs posteriorly, 3rd and 4th tarsomeres almost globose. Middle leg $: F_{2}$ short-setose above, beneath with an av and a pv rows of $4-5$ bristles ( $2 \times t_{2}$ thickness) becoming shorter apically ; $t_{2}$ clothed with long setae and bearing a strong (at $1 / 3$ ) and a weaker (at $1 / 2)$ ad bristles, 2 pd bristles (at 0.6 and 0.9 ), a strong pv bristle (at 0.6 ), and several strong apical bristles ; tarsus almost as in front leg. Hind leg $; \mathrm{F}_{3} 6.5 \mathbf{x}$ as long as thick, moderately thickened, clothed with dorsal and ventral setae 0.7-0.9 $\times$ as long as $t_{3}$ thickness, bearing 1 preapical ad bristle, an av row of 9-10 strong spines (the longest at 0.7 is $0.8 \times$ as long as $f_{3}$ thickness, apical 3-4 arising from tuberculate sockets), 4-5 short strong $\mathrm{v}$ spines arising from weakly tuberculate sockets on apical $1 / 3$ of $f_{3}$, and a pv row of longish setae which become shorter and thicker towards $f_{3}$ tip; $t_{3}$ geniculate basally, only slightly sinuate

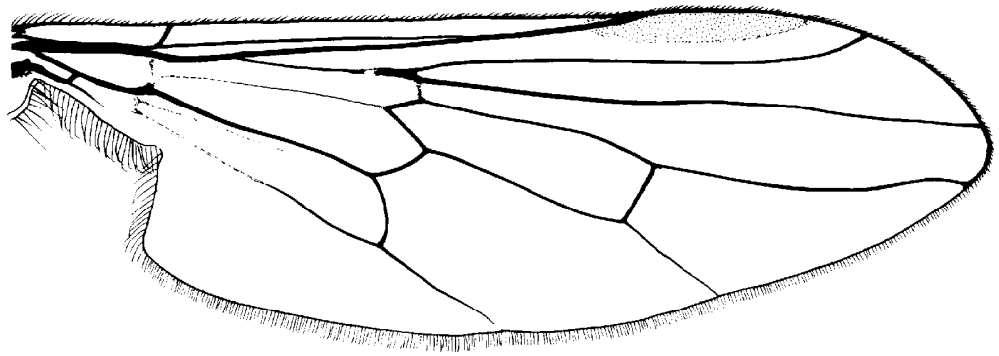

Fig. 1. Wing of Syneches hirashimai sp. nov. 
ventrally, clothed with longish hairs $\left(0.6-0.8 \times \mathrm{t}_{3}\right.$ thickness) and a row of longer $\mathrm{d}$ setae ; hind tarsus thicker than the middle, setose as in the latter.

Abdomen moderately stout, terga clothed with dark brown to black long setae, sternum with short yellow hairs. Genitalia : Tergal lobe distally divided into a long slender dorsal process and a broad, roundly ended ventral lobe which is weakly curved inwardly ; hypandrium broad, almost parallel-sided, but somewhat dilated on posterior $1 / 4$, posterior portion weakly bilobate, each lobe with weakly rounded margin, posteromedian incision of hypandrium rather weak, hypandrium bearing 5 pairs of bristles on posterior $1 / 5,2-3$ of them much stronger ; paramere entirely sclerotized, lamellate, and bilobate apically; aedeagus with much inflated apex, of which lateral portions are much expanded, but are not ornamented with teeth.

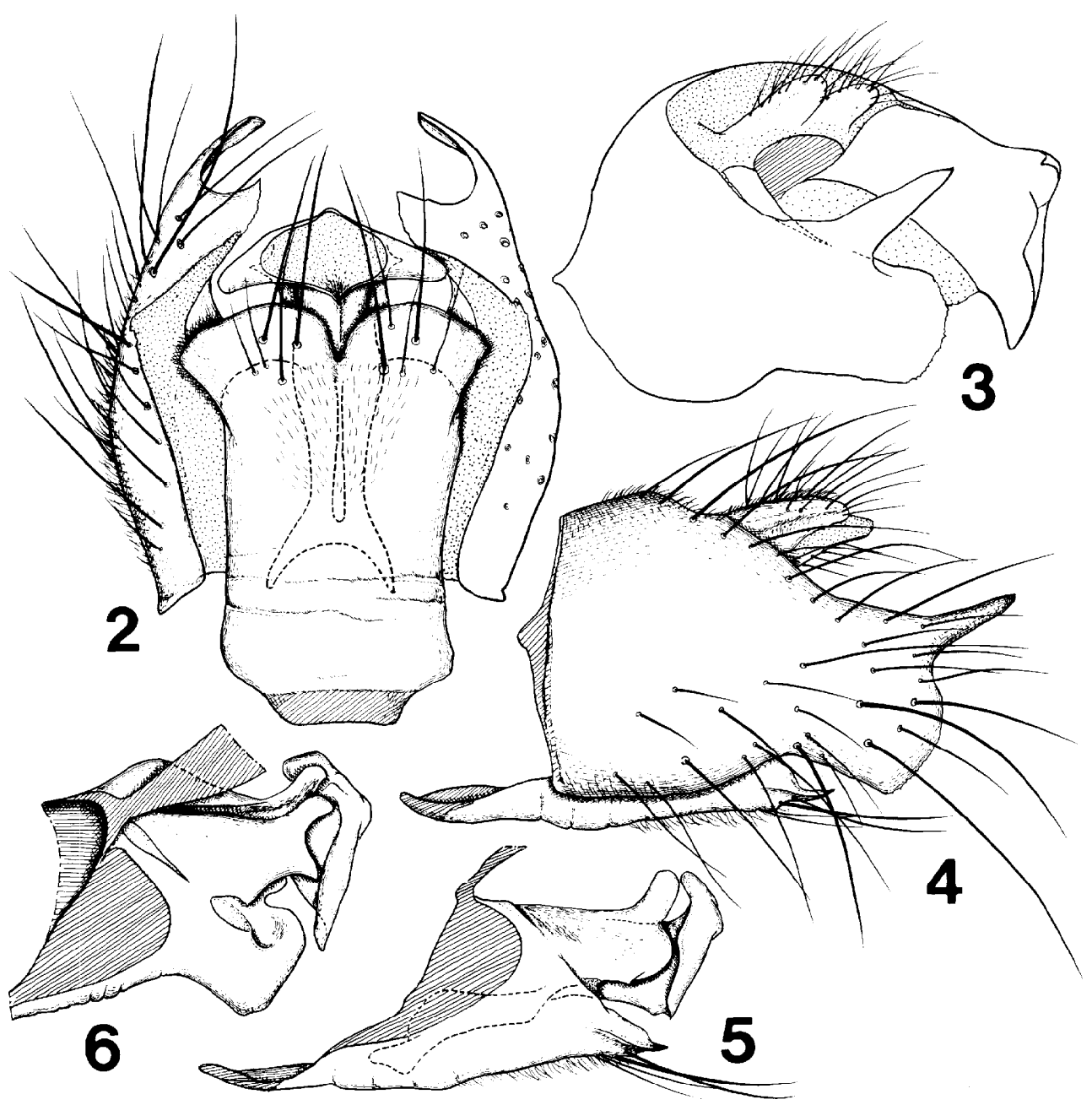

Figs. 2-6. Male genitalia of Syneches hirashimai sp. nov. 2. Ventral aspect, cerci omitted. 3. Posterodorsal aspect of epandrium and cerci. 4. Lateral aspect. 5. Lateral aspect of hypandrium and phallus. 6. Anterodorsal aspect of posterior half of hypandrium and phallus. 
Length: Body $5.0 \mathrm{~mm}$; wing $5.0 \mathrm{~mm}$.

DisTRIBUTION : Borneo.

Holotype 6, Gowback, Sabah, Borneo, 13. xi. 1963, (Y. Hirashima). The holotype is preserved in the Empidid collection of the Biological Laboratory, College of General Education, Kyushu University.

REMARKS : Syneches hirashimai is similar to S. subdeficiens Frey, 1938 from the Philippines in colouration of the thorax and legs. But the new species is easily distinguished from subdeficiens by the following respects. The stigma of the wing is much paler in the new species. It is dark brown and occupies almost entire space of apical portion of the cell $\mathrm{R}_{2+3}$ in subdeficiens. The ventral spines of the hind femur have tuberculate sockets only on the apical portion of the femur in the new species, while in subdeficiens almost all the spines have tuberculate sockets. The hind tibia of the new species is rather simple, while in subdeficiens the tibia has a series of ventral tubercles, each of which bears a longish ventral setae. 